\title{
Mercury, cadmium and lead in black scabbardfish (Aphanopus carbo Lowe, 1839) from mainland Portugal and the Azores and Madeira archipelagos
}

\author{
VALENTINA COSTA ${ }^{1}$, HELENA MARIA LOURENÇO ${ }^{2}$, IVONE FIGUEIREDO ${ }^{3}$, \\ LUCÍLIA CARVALHO ${ }^{4}$, HUMBERTO LOPES ${ }^{1}$ INÊSS FARIAS ${ }^{3}$, LUÍS PIRES ${ }^{1}$, \\ CLÁUDIA AFONSO ${ }^{2}$, ANA RITA VIEIRA ${ }^{5}$, MARIA LEONOR NUNES ${ }^{2}$ \\ and LEONEL SERRANO GORDO ${ }^{5}$ \\ ${ }^{1}$ Departamento de Oceanografia e Pescas, Universidade dos Açores, R. Comendador Fernando da Costa, \\ 9901-862 Horta, Portugal. E-mail: valentina@uac.pt \\ ${ }^{2}$ Unidade de Valorização dos Produtos da Pesca e da Aquicultura, INRB, L-IPIMAR, Av. Brasília, \\ 1449-006 Lisboa, Portugal. \\ ${ }^{3}$ Unidade de Recursos Marinhos e Sustentabilidade, INRB, L-IPIMAR, Av. Brasília, 1449-006 Lisboa, Portugal. \\ ${ }^{4}$ Departamento de Estatística e Investigação Operacional, Faculdade de Ciências da Universidade de Lisboa, Edifício C6, \\ Campo Grande, 1749-016 Lisboa, Portugal. \\ ${ }^{5}$ Departamento de Biologia Animal e Centro de Oceanografia, Faculdade de Ciências da Universidade de Lisboa, \\ Bloco C2, Campo Grande, 1749-016 Lisboa, Portugal.
}

\begin{abstract}
SUMMARY: Total mercury (THg), cadmium $(\mathrm{Cd})$ and lead $(\mathrm{Pb})$ concentrations were investigated in muscle, liver and gonad tissue of black scabbardfish (Aphanopus carbo) from the southern northeast Atlantic at three Portuguese locations: the mainland and the archipelagos of the Azores and Madeira. Particular emphasis was placed on the comparison of metal levels between geographic locations. Other factors such as size, sex and sexual maturity were also investigated. The median concentrations ( $\mathrm{mg} / \mathrm{kg} \mathrm{ww})$ of THg showed a decreasing trend in the order liver $>$ muscle $>$ gonad. Cadmium levels decreased in the order liver $>$ gonad $>$ muscle and $\mathrm{Pb}$ levels decreased in the order gonad $>$ liver $>$ muscle. According to the EU limits, the concentration observed in some specimens, particularly those of $\mathrm{THg}$, raises some food safety concerns. In all the tissues the concentrations of each toxic metal differed between locations. In particular: i) THg concentrations in specimens from Madeira were significantly higher than those from the Azores and the mainland; ii) Cd levels in specimens from the mainland were significantly higher than those from Madeira and the Azores; and iii) for all analysed tissues Pb levels were significantly higher in specimens from the Azores than in those from the mainland. The differences in toxic metal levels between locations were further discussed in relation to aspects of species dynamics and the influence of the main environmental features at each location.
\end{abstract}

Keywords: total mercury, cadmium, lead, muscle, gonad, liver, Aphanopus carbo, Northeast Atlantic.

RESUMEN: Mercurio, cadmio y Plomo en el sable negro (Aphanopus Carbo Lowe, i 839) De Portugal Continental Y DE LOS ARCHIPIÉLAgos DE MADEIRA Y AZORES. - Se investigaron las concentraciones de mercurio total (THg), cadmio $(\mathrm{Cd})$ y plomo $(\mathrm{Pb})$ en músculo, hígado y gónada de sable negro en muestras recogidas en tres regiones del sur del Atlántico noreste: Portugal continental y archipiélagos de Madeira y Azores. Se puso especial énfasis en la comparación entre regiones. También fueron analizados los factores talla, sexo y madurez sexual. Una tendencia decreciente fue observada en las concentraciones medias ( $\mathrm{mg} / \mathrm{kg} \mathrm{ww}$ ) de THg entre hígado, músculo y gónadas. Los niveles de Cd decrecieron entre hígado, gónadas y músculo, y en caso de los niveles de $\mathrm{Pb}$, decrecieron entre gónadas, hígado y músculo. De acuerdo con las regulaciones de la UE sobre el consumo de esta especie, las concentraciones observadas en algunos especímenes, particularmente de $\mathrm{THg}$, han suscitado inquietudes relacionadas con la seguridad alimentaria. El factor región fue significativo en las diferencias entre los tres metales para todos los tejidos. Particularmente: i) la concentración de THg en especímenes de Madeira fue significativamente más alta que en Azores y en el continente; ii) los niveles de Cd en especímenes del Continente fueron 
significativamente más altos que en Madeira y en Azores; y iii) en todos los tejidos analizados, los niveles de Pb fueron significativamente más elevados en Azores que en el continente. Estas discrepancias en los niveles tóxicos entre localizaciones son discutidas en relación con aspectos de dinámica de la especie y la influencia de características ambientales de cada región.

Palabras clave: mercurio total, cadmio, plomo, músculo, gónada, hígado, Aphanopus carbo, Atlántico Nordeste.

\section{INTRODUCTION}

Most fish species accumulate in their tissues contaminants present in the environment and in food (Dugo et al., 2006). Among the trace elements of general concern, total mercury $(\mathrm{THg})$, cadmium $(\mathrm{Cd})$ and lead $(\mathrm{Pb})$ are of major potential ecotoxic significance in the marine environment (Falcó et al., 2006; Storelli, 2008). Although these metals do not play any known metabolic function, they can cause damage in the human body, interfering in the functioning of many of its basic systems: renal, cardiovascular, gastrointestinal, endocrine, nervous, etc. (Pérez-Cid et al., 2001). Mercury is a highly toxic metal that occurs naturally in the environment as a result of metal volatilisation associated with volcanic events or cinnabar deposits (mercuric sulphide, $\mathrm{HgS}$ ). The anthropogenic contribution to environmental mercury is derived from metal extraction (e.g. gold mining) and from its direct or indirect industrial uses. Unlike cadmium and lead, inorganic mercury can be methylated and form organic mercury compounds covalently bound to carbon, such as methylmercury $\left(\mathrm{CH}_{3} \mathrm{Hg}\right)$, which is one of its most toxic forms (Hrudey et al., 1996). In addition, mercury is the only known metal that consistently biomagnifies through the food chain, i.e. predators accumulate higher mercury concentrations than those found in their prey (Monteiro et al., 1996). Cadmium is a stable, ubiquitous toxic metal that is not abundant in its pure state in the environment. It is a by-product of zinc, lead, and copper mining and smelting that enters the organism through the diet and is concentrated mostly in the kidneys and the liver (EPA, 1999). Fossil fuel combustion is the major source of pollutant lead in the atmosphere. Later it enters the marine environment through the atmospheric deposition by the wet and dry removal process (Paterson, 1987). Lead can accumulate in the bone, affect the central nervous system and interfere with the metabolism of hemoglobin. Living organisms tend to bioaccumulate mercury, cadmium and lead since they absorb the toxic substances at a greater rate than they are metabolised or excreted. As a result, bioaccumulation of toxic metals poses a serious threat to animal health, including that of humans.
The growing concerns about the presence of toxic metals in food led the European Commission to establish legal limits for several chemical contaminants. For black scabbardfish (Aphanopus carbo), maximum permissible levels of mercury, cadmium and lead are $1.0 \mathrm{mg} / \mathrm{kg}, 0.05 \mathrm{mg} / \mathrm{kg}$ and $0.30 \mathrm{mg} / \mathrm{kg}$, respectively (EU 2006, 2008).

The black scabbardfish (family Trichuridae) is a top predator that inhabits the NE Atlantic slopes around isolated island groups and seamounts between 200 and $1600 \mathrm{~m}$ in depth (Parin, 1986; Martins and Ferreira, 1995). Juveniles are mesopelagic and adults are benthopelagic, migrating to midwater at night to feed on fish, squid and crustaceans (Merrett and Haedrich, 1997). This species is appreciated by fish consumers in Portugal, especially in the Madeira archipelago.

The aim of this study was to characterise the levels of mercury, cadmium and lead in muscle, gonad and liver of black scabbardfish caught off three different Portuguese regions (the mainland, the Azores and Madeira). Factors such as region, length, sex, and maturity stage that can influence the variability of metal concentrations in black scabbardfish in those three tissues were also investigated. Lastly, metal levels obtained in tissues were compared with established limits defined by the European Community Regulation (2006, 2008).

\section{MATERIALS AND METHODS}

Black scabbardfish samples were obtained on a routine monthly basis at the landing ports of Sesimbra (mainland Portugal) and Funchal (Madeira). They were obtained on an irregular basis at Santa Maria (the Azores) (Fig. 1), since there is no fishery targeting the species in this archipelago. For the purpose of this study, samples were collected in February-March, June-July and October-November (the spawning period in Madeiran waters, Figueiredo et al., 2003) from May 2005 to December 2007 but, due to problems involving sampling dispatch, it was only possible to sample two seasons in the Azores and Madeira. For each individual, total length $(\mathrm{mm})$, total weight $(\mathrm{g})$ and sex were recorded. Maturity 


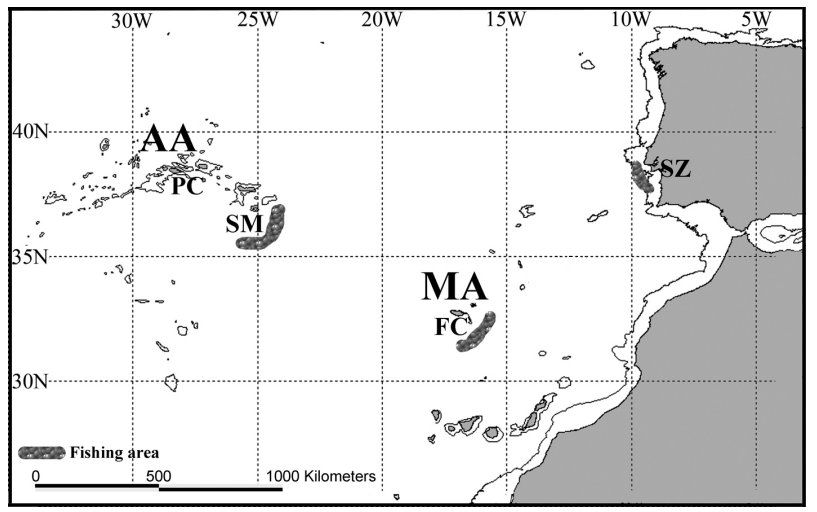

FIG. 1. - Map of the southern northeast Atlantic with the sampling locations of black scabbardfish and the $1000 \mathrm{~m}$ isobath. AA, Azores Archipelago; FC, Funchal; MA, Madeira Archipelago; PC, Pico Island; SM, Santa Maria Island; SZ, Sesimbra (mainland Portugal).

stage was assigned for each sampled individual according to the scale proposed by Gordo et al. (2000). The otoliths were removed and age was assessed by counting annuli in sectioned otoliths (Vieira et al., 2009). Samples of dorsal muscle (post-opercular region), gonad and liver were collected $( \pm 10 \mathrm{~g})$, stored in a plastic bag and preserved at $-20^{\circ} \mathrm{C}$. The frozen samples were sent to two laboratories (DOPIMAR, UAç and INRB, IP/L-IPIMAR) for mercury, and cadmium and lead analysis, respectively. The number of samples analysed by each laboratory was different because the procedure for cadmium and lead analysis uses much more material than the method for $\mathrm{THg}$ analysis. Prior to the analysis, samples were defrosted at room temperature and homogenised in a food blender. All laboratory ware was cleaned with $\mathrm{HNO}_{3}(10 \%)$ for $48 \mathrm{~h}$ and rinsed with ultrapure water $(18.2 \mathrm{M} \Omega \mathrm{cm})$ to avoid contamination. Chemical reagents were pro-analysis or superior. Mercury, cadmium and lead concentrations were reported as milligrams per kilogram on a wet weight basis (mg/ $\mathrm{kg} \mathrm{ww}$ ). All analyses were carried out at least in duplicate; an external calibration method was used for quantitative analysis.

\section{Total mercury analysis}

Total mercury ( $\mathrm{THg}$ ) was determined by cold vapour atomic absorption spectrophotometry (CVAAS) according to the procedures described by Hatch and Ott, (1968). Tissue sub-samples (0.2-1 g ww) were subjected to a wet mineralisation by digestion in sulphuric acid and subsequently oxidised to $\mathrm{Hg}^{2+}$, using potassium permanganate. Mercury quantification was performed with a Bacharach Coleman Model 50D Mercury Analyser System.
The $\mathrm{Hg}^{2+}$ was reduced to $\mathrm{Hg}^{0}$ by adding stannous chloride. The volatile $\mathrm{Hg}^{0}$ was bubbled into the closed system of the analyser and the absorption was measured (wavelength at $253.7 \mathrm{~nm}$ ). The detection limit (expressed in $\mathrm{mg} / \mathrm{kg} \mathrm{ww}$ ) was 0.012 . Total mercury concentrations in the sample were determined in duplicate using an external calibration. The linear calibration curve was obtained by measuring the absorbance of six standards, with different concentrations, which were prepared by dilution from a $1000 \mathrm{mg} \mathrm{l}^{-1}$ mercuric chloride solution (Merck, Germany). Analytical quality control was provided through within- and betweenlaboratory quality control procedures employed throughout the study period. The accuracy of the method (expressed as relative error) was within $10 \%$, and was monitored throughout the analysis of the certified reference materials (dogfish muscle, DORM-2; dogfish liver, DOLT-2) from the National Research Council of Canada, Ottawa. The results obtained in this study $(4.49 \pm 0.25 \mathrm{mg} / \mathrm{kg}$; $2.14 \pm 0.16 \mathrm{mg} / \mathrm{kg}$ ) were in the range of the certified values $(4.64 \pm 0.26 \mathrm{mg} / \mathrm{kg}$ and $2.14 \pm 0.28 \mathrm{mg} /$ $\mathrm{kg}$ ) for DORM-2 and DOLT-2, respectively. The precision (or reproducibility) of the method (expressed as the coefficient of variation of duplicates within and between batches) was within the usual $10 \%$ for total mercury determinations in biological samples (Saltzman et al., 1983). Interference with sensitivity due to matrix and pre-treatment were assessed by the method of standard additions before the wet mineralisation digestion, and the average recoveries of added inorganic mercury was $96.8 \%$ (s.d. $=11.3, \mathrm{n}=12$ ).

\section{Cadmium and lead analysis}

Determination of cadmium and lead levels was performed by flame atomic absorption spectrometry (FAAS), according to the procedures described by Jorhem (2000). Edible portion samples (10 g) were dry-ashed at $500^{\circ} \mathrm{C}$ through a gradual temperature increase. Ash was dissolved in concentrated nitric acid and the solution obtained was evaporated to dryness. The final residue was dissolved once again with $5 \mathrm{ml}$ nitric acid $15 \%(\mathrm{v} / \mathrm{v})$ and transferred to 10 -ml volumetric flasks, and final volumes were adjusted with ultrapure water. Quantification of these elements was performed using a Spectr AA-20 Varian spectrophotometer with deuterium background correction $(\lambda=228.8 \mathrm{~nm}$ for $\mathrm{Cd}$ and $\lambda=217.0 \mathrm{~nm}$ 
for $\mathrm{Pb}$ ). Detection limits (expressed in $\mathrm{mg} / \mathrm{kg} \mathrm{ww}$ ) were $0.02(\mathrm{Cd})$ and $0.01(\mathrm{~Pb})$. Certified reference material TORT-2 (Lobster hepatopancreas), from the National Research Council of Canada, was tested in the same conditions as the samples in order to assess analytical method accuracy. The results obtained in this study $(0.35 \pm 0.06 \mathrm{mg} / \mathrm{kg}$ for $\mathrm{Pb}$ and $26.8 \pm$ $0.1 \mathrm{mg} / \mathrm{kg}$ for $\mathrm{Cd}$ ) were in the range of the certified values $(0.35 \pm 0.13 \mathrm{mg} / \mathrm{kg}$ for $\mathrm{Pb}$ and $26.7 \pm 0.6 \mathrm{mg} /$ $\mathrm{kg}$ for $\mathrm{Cd}$ ). Concentrations of $\mathrm{Pb}$ and $\mathrm{Cd}$ were calculated from linear calibration plots obtained by measurement of the absorbance of six standard solutions. These solutions were prepared by dilution of 1000 $\mathrm{mg} \mathrm{l}^{-1}$ lead and cadmium nitrate solutions (Merck, Germany).

\section{Statistical analysis}

For muscle, liver and gonad samples, the differences in log-transformed $\mathrm{THg}, \mathrm{Cd}$ and $\mathrm{Pb}$ concentrations between the classes of region, sex and maturity stage were explored through box plots.
Data logarithmic transformation was applied to reduce the wide range of values and thus facilitate the joint plot of the three tissues for each factor. To evaluate the contribution of region, sex, maturity stage and covariate length, univariate general linear models (GLM) were adjusted to data for each combination of tissue and toxic metal. Multiple comparisons of estimated marginal means of metal concentrations between different locations were performed using the least significant difference test (LSD test). These tests were used to evaluate the statistical significance of the differences in concentration between locations. In all statistical analyses the level of significance was set at 0.05 .

\section{RESULTS}

The range of total length (mm); the sample size by sex; the maturity stages; the total number of specimens analysed by region; the mean, range age

TABLE 1. - Summary of the descriptive statistics of the mercury analyses for the three tissues from the Azores, Madeira and Mainland: range of total length $(\mathrm{mm})$; number of specimens by sex; maturity stages available for each geographic region; number of specimens sampled (N); mean and age range (years) and number of specimens aged; and median and range of total mercury concentration ( $\mathrm{mg} / \mathrm{kg} \mathrm{ww}$ ).

\begin{tabular}{lccc}
\hline & Azores & Madeira & Mainland \\
\hline Total length & $625-1370$ & $1165-1481$ & $840-1293$ \\
Sex (F/M) & $84 / 43$ & $50 / 4$ & $57 / 64$ \\
Maturity stage & I, II, III, IV, V & II, III, IV, V & I, II \\
N & 135 & $12(10-15 ; \mathrm{n}=20)$ & 121 \\
Age & $8(6-12 ; \mathrm{n}=35)$ & $0.41(0.07-1.40)$ & $8(5-12 ; \mathrm{n}=104)$ \\
Total mercury & $0.19(0.03-2.74)$ & $5.83(1.10-50.23)$ & $0.18(0.05-0.94)$ \\
$\quad$ Gonad & $1.62(0.43-45.9)$ & $1.45(0.52-2.76)$ & $1.56(0.42-7.15)$ \\
$\quad$ Liver & $0.71(0.27-2.19)$ & & $0.69(0.27-1.4)$ \\
$\quad$ Muscle & & & \\
\hline
\end{tabular}

TABLE 2. - Summary of the descriptive statistics of the cadmium and lead analyses for the three tissues from the Azores, Madeira and Mainland: range of total length $(\mathrm{mm})$, number of specimens by sex, maturity stages available for each geographic region; number of specimens sampled $(\mathrm{N})$ and median and range of lead and cadmium concentration $(\mathrm{mg} / \mathrm{kg} \mathrm{ww})$.

\begin{tabular}{lccc}
\hline Region & Azores & Madeira & Mainland \\
\hline Total length & $945-1225$ & $1117-1481$ & $834-1330$ \\
Sex (F/M) & $23 / 16$ & $32 / 23$ & $120 / 100$ \\
Maturity stage & II, III, IV & II, III, IV, V & I, II, III \\
n & 39 & 55 & 220 \\
Cadmium & $0.19(0.04-0.22)$ & $0.1(0.03-0.71)$ & $0.26(0.04-1.30)$ \\
$\quad$ Gonad & $3.15(0.58-13.67)$ & $9.2(2.63-19.81)$ & $8.08(2.56-30.24)$ \\
Liver & $<0.02 *(<0.02 *-0.04)$ & $<0.02 *(<0.02 *-0.02)$ & $0.02(<0.02 *-0.08)$ \\
Muscle & $0.15(0.07-1.15)$ & $0.05(<0.01 *-0.17)$ & $0.05(0.02-0.067)$ \\
Lead & $0.1(0.03-0.22)$ & $0.03(<0.01 *-0.06)$ & $0.04(<0.01 *-0.51)$ \\
$\quad$ Gonad & $0.05(0.03-0.11)$ & $0.04(0.03-0.12)$ & $0.15)$ \\
$\quad$ Liver & & & \\
$\quad$ Muscle & & &
\end{tabular}

* values below the detection limit: $\mathrm{Cd}=0.02 \mathrm{mg} / \mathrm{kg} ; \mathrm{Pb}=0.01 \mathrm{mg} / \mathrm{kg}$ 
TABLE 3. - Significance of p-values for each factor considered in linear models adjusted to total mercury, cadmium and lead levels in gonad, liver and muscle.

\begin{tabular}{|c|c|c|c|c|c|c|}
\hline Metal & Tissue & $\mathrm{R}^{2}$ & Region & Sex & Maturity stage & Length \\
\hline Total mercury & $\begin{array}{l}\text { Gonad } \\
\text { Liver } \\
\text { Muscle }\end{array}$ & $\begin{array}{c}0.19 \\
0.3 \\
0.59\end{array}$ & $\begin{array}{l}<0.001 \\
<0.001 \\
<0.001\end{array}$ & $\begin{array}{c}\text { ns } \\
<0.001 \\
<0.001\end{array}$ & $\begin{array}{l}<0.001 \\
<0.001 \\
<0.001\end{array}$ & $\begin{array}{l}<0.001 \\
<0.001 \\
<0.001\end{array}$ \\
\hline Cadmium & $\begin{array}{l}\text { Gonad } \\
\text { Liver } \\
\text { Muscle }\end{array}$ & $\begin{array}{c}0.27 \\
0.19 \\
0.1\end{array}$ & $\begin{array}{l}<0.05 \\
<0.01 \\
<0.001\end{array}$ & $\begin{array}{l}\mathrm{ns} \\
\mathrm{ns} \\
\mathrm{ns}\end{array}$ & $\begin{array}{c}<0.05 \\
\mathrm{~ns} \\
\mathrm{~ns}\end{array}$ & $\begin{array}{l}\mathrm{ns} \\
\mathrm{ns} \\
\mathrm{ns}\end{array}$ \\
\hline Lead & $\begin{array}{l}\text { Gonad } \\
\text { Liver } \\
\text { Muscle }\end{array}$ & $\begin{array}{l}0.36 \\
0.19 \\
0.08\end{array}$ & $\begin{array}{l}<0.001 \\
<0.05 \\
<0.01\end{array}$ & $\begin{array}{l}\mathrm{ns} \\
\mathrm{ns} \\
\mathrm{ns}\end{array}$ & $\begin{array}{l}\mathrm{ns} \\
\mathrm{ns} \\
\mathrm{ns}\end{array}$ & $\begin{array}{l}\mathrm{ns} \\
\mathrm{ns} \\
\mathrm{ns}\end{array}$ \\
\hline
\end{tabular}

ns $=$ not significant $(\mathrm{p}>0.05)$

(years) and the number of specimens aged; and the median and range of metal concentrations are summarised in Tables 1 (mercury) and 2 (cadmium and lead). There were differences in the length ranges between geographic locations: specimens from Madeira were larger (total length $>1150 \mathrm{~mm}$ ) than those from the Azores and the mainland (Tables 1 and 2). The sex ratio estimates varied between locations (Table 1). Maturity stages (MS) were not all found at each of the three locations, and in particular no mature individuals were observed off mainland Portugal (lack of MS IV and V).

\section{Mercury}

Concentrations of total mercury differed between tissues: they were highest in the liver, and decreased from muscle to gonad (Table 1). The adjusted GLM (Table 3) showed that the factors region, maturity stage and covariate length explained a fairly high percentage of the variance in mercury concentrations in liver $\left(\mathrm{R}^{2}=0.30\right)$ and muscle $\left(\mathrm{R}^{2}\right.$ $=0.59)$. For gonad this variance was lower $\left(\mathrm{R}^{2}\right.$ $=0.19$ ). Total mercury levels were significantly different between regions and maturity stages ( $p<0.001$ in both cases) for all tissues. Length was also significant for all tissues $(\mathrm{p}<0.001)$. The levels of total mercury differed between sexes in liver and muscle ( $\mathrm{p}<0.001$ for both), but no differences were observed in $\operatorname{gonad}(\mathrm{p}=0.93)$.

For the three tissues, the highest total mercury levels were registered off Madeira and the lowest off the mainland (Fig. 2a). The total mercury levels in liver (maximum of $50.23 \mathrm{mg} / \mathrm{kg}$ ww recorded in one specimen from Madeira) were commonly much higher than those in the other two tissues (Table 1). Total mercury in gonad showed the lowest levels, with a minimum $(0.03 \mathrm{mg} / \mathrm{kg})$ and a maximum $(2.74 \mathrm{mg} / \mathrm{kg})$ in specimens from the Azores. Accordingly, the levels registered for the muscle were higher, respectively $1.45,0.71$ and $0.69 \mathrm{mg} /$ $\mathrm{kg}$ ww for Madeira, the Azores and the mainland (Table 1). The LSD test indicated that total mercury means in muscle from specimens caught off the Azores and the mainland were significantly lower $(\mathrm{p}<0.001)$ than those from specimens caught off Madeira (Table 4). In gonad and liver, means were not statistically different between the mainland and the Azores. For muscle and liver the differences between Madeira and the mainland and between Madeira and the Azores were statistically significant $(\mathrm{p}<0.001$; Table 4$)$. The mean total mercury levels in muscle and liver were significantly higher $(\mathrm{p}<0.001)$ in females than in males (Fig. 2b, Table $3)$. Although males showed higher mean mercury concentrations in gonad than females, this difference was not statistically significant (Fig. 2b; Table 3). Total mercury levels increased from maturity stage I to maturity stage IV and decreased in the post-spawning stage (MS V; Fig. 2c). The highest variability of total mercury levels was registered for maturity stage II (Fig. 2c).

\section{Cadmium}

In all three regions the cadmium concentration was higher in liver tissue than in gonad or muscle (Table 2 and Fig. 3a). The highest cadmium concentration was found in liver of fish caught off the mainland (30.24 mg/kg ww) and the lowest (below $0.02 \mathrm{mg} / \mathrm{kg} \mathrm{ww}$ ) in muscle from specimens of all three regions. The cadmium concentration in gonads ranged from 0.03 (Madeira) to $1.30 \mathrm{mg} / \mathrm{kg} \mathrm{ww}$ (mainland). 

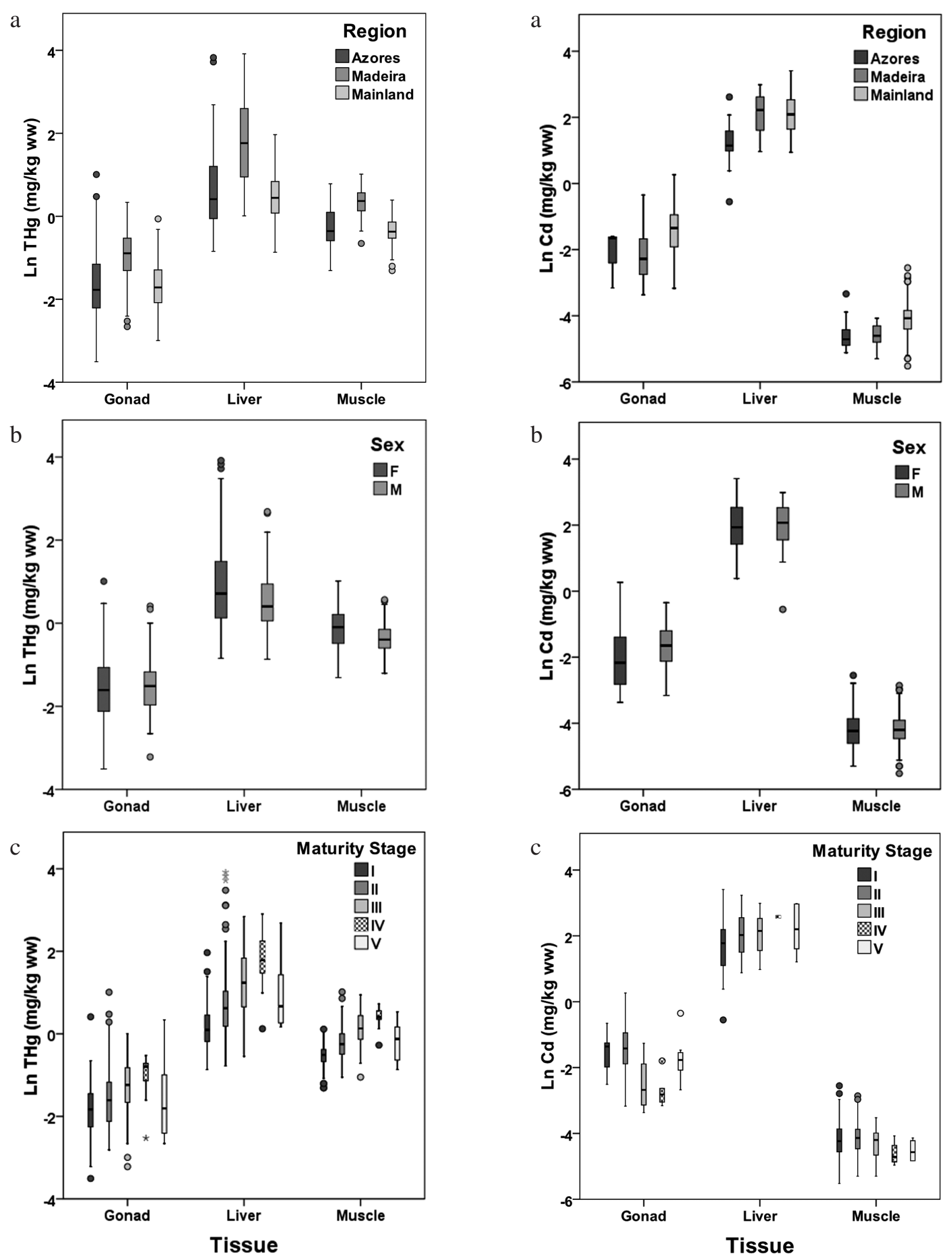

FIG. 2. - Box plots of total mercury concentrations by (a) region, (b) sex, and (c) maturity stage. Each box plot presents the median, the $1^{\text {st }}$ and $3^{\text {rd }}$ quartiles, the maximum and the minimum. The circles correspond to the outliers and the asterisks are the extreme outliers.

FIG. 3. - Box plots of cadmium concentrations by (a) region, (b) sex, and (c) maturity stage. Each box plot presents the median, the $1^{\text {st }}$ and $3^{\text {rd }}$ quartiles, the maximum and the minimum. The circles correspond to the outliers and the asterisks are the extreme outliers. 
a
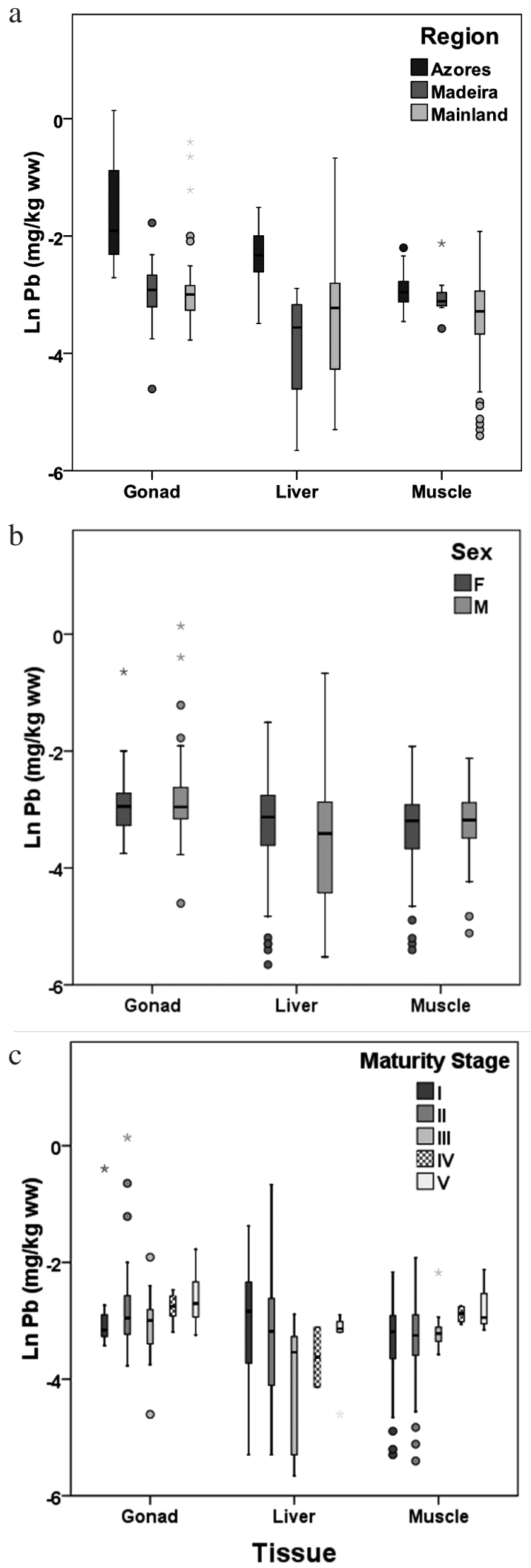

FIG. 4. - Box plots of lead concentrations by (a) region, (b) sex, and (c) maturity stage. Each box plot presents the median, the $1^{\text {st }}$ and $3^{\text {rd }}$ quartiles, the maximum and the minimum. The circles correspond to the outliers and the asterisks are the extreme outliers.
The adjusted GLM (Table 3) showed that region, maturity stage and length explained a low percentage of the variance of cadmium concentrations in the three tissues (liver; $\mathrm{R}^{2}=0.19$; muscle, $\mathrm{R}^{2}=0.10$ and gonad, $\mathrm{R}^{2}=0.27$ ). For all the tissues, the adjusted GLM (Table 3) revealed that region was a significant factor in explaining concentration differences in muscle $(\mathrm{p}<0.001)$, liver $(\mathrm{p}<0.01)$ and gonad $(\mathrm{p}<0.05)$. The maturity stage was only significant in the case of $\operatorname{gonad}(\mathrm{p}<0.05)$. The pairwise comparison indicated that cadmium mean concentrations in muscle and liver differed significantly $(\mathrm{p}<0.001)$ between the Azores and the mainland (Table 4). For gonad tissue, significant differences $(p<0.01)$ were found only between Madeira and the mainland.

Male gonad showed higher median cadmium levels than female gonad, but the difference was not statistically significant ( $>0.05)$ (Fig. 3b, Table 3). Differences between maturity stages were detected for gonad ( $p<0.05$, Table 3 ). Maturity stages III and IV showed the lowest median levels and in the remaining stages median values were similar (Fig. 3c).

\section{Lead}

In general, lead showed a decreasing gradient from gonad to liver and lastly to muscle (Table 2). The region was the only factor that explained the variance in lead concentrations for all analysed tissues (liver, $\mathrm{R}^{2}=0.19$; muscle, $\mathrm{R}^{2}=0.08$ and gonad, $\left.\mathrm{R}^{2}=0.36\right)$ (Table 3), of which the median lead levels were highest for the Azores (Table 2). The maximum concentration $(1.15 \mathrm{mg} / \mathrm{kg} \mathrm{ww})$ was observed in the gonad of a specimen from the Azores and the minimum $(<0.01 \mathrm{mg} / \mathrm{kg} \mathrm{ww})$ in the liver of specimens from Madeira and the mainland. The median concentrations in muscle were similar within all the regions $(0.04-0.05 \mathrm{mg} / \mathrm{kg} \mathrm{ww}$; Table 2). The pairwise comparisons (Table 4) showed that lead levels in liver and gonad differed significantly between Madeira and the Azores $(p<0.05$ and $p<0.001$, respectively). The mainland and the Azores differed from each other in terms of concentrations in all three tissues $(\mathrm{p}<0.001$ for gonad and muscle; $\mathrm{p}<0.05$ for liver; Table 4). Lead levels in all three tissues did not differ between sexes (Fig. 4b). In liver, the ranges of lead levels for the first three maturity stages (I, II and III) were fairly wide, exhibiting a decreasing trend from stage I to IV. Median levels of stage V were similar to those of stage II (Fig. 4c). 
TABLE 4. - Multiple comparisons between total mercury, cadmium and lead estimated marginal means by region for each tissue (mean difference; standard error; significance of p-value).

\begin{tabular}{llcrr}
\hline Metal & Tissue & Azores $v$ s Madeira & Azores $v$ s Mainland & Madeira $v s$ Mainland \\
\hline \multirow{2}{*}{ Total mercury } & Gonad & $-0.15 ; 0.05^{(* * *)}$ & $0.02 ; 0.04^{(\mathrm{ns})}$ & $0.17 ; 0.06^{(* *)}$ \\
& Liver & $-3.81 ; 0.90^{(* * *)}$ & $0.41 ; 0.72^{(\mathrm{ns})}$ & $4.22 ; 1.09^{(* * *)}$ \\
& Muscle & $-0.32 ; 0.05^{(* * *)}$ & $-0.11 ; 0.04^{(* *)}$ & $0.21 ; 0.07^{(* * *)}$ \\
Cadmium & Gonad & $0.00 ; 0.11^{(\mathrm{ns})}$ & $-0.20 ; 0.12^{(\mathrm{ns})}$ & $-0.20 ; 0.07^{(* *)}$ \\
& Liver & $-7.01 ; 2.81^{(*)}$ & $-5.79 ; 1.74^{(* *)}$ & $1.22 ; 2.65^{(\mathrm{ns})}$ \\
& Muscle & $0.00 ; 0.00^{(\mathrm{ns})}$ & $-0.01 ; 0.00^{(* * *)}$ & $-0.01 ; 0.00^{(*)}$ \\
Lead & Gonad & $0.44 ; 0.09^{(* * *)}$ & $0.37 ; 0.09^{(* * *)}$ & $-0.07 ; 0.06^{(\mathrm{ns})}$ \\
& Liver & $0.08 ; 0.04^{(*)}$ & $0.05 ; 0.02^{(*)}$ & $-0.03 ; 0.03^{(\mathrm{ns})}$ \\
& Muscle & $0.01 ; 0.01^{(\mathrm{ns})}$ & $0.02 ; 0.00^{(* *)}$ & $0.00 ; 0.01^{(\mathrm{ns})}$ \\
\hline
\end{tabular}

Significance (p-values): ${ }^{(\mathrm{ns})} \mathrm{p} \geq 0.05$ (*) $^{(*<}<0.05$; $^{(*)} \mathrm{p}<0.01$; $^{(* *)} \mathrm{p}<0.001$

\section{DISCUSSION}

Copper, zinc and iron are essential for fish metabolism but mercury, cadmium and lead have no known role in biological systems. These non-essential metals use a similar metabolic pathway to that of essential minerals, being assimilated by fish from water, food or sediment, and consequently accumulating in their tissues (Canli and Atli, 2003). The concentration of mercury is enhanced by the high availability of its stable organic form below the thermocline. This form, especially methylmercury, occurs in the cold deep waters of the north Atlantic and is assimilated by organisms four times more efficiently than the inorganic form (Mason et al., 1995).

In general, deepwater species show an increased potential for accumulating trace metals (Gordon et $a l ., 1995)$. It has also been reported that mercury accumulation in fish increases with trophic level, age, size and depth (Riisgård and Hansen, 1990; Monteiro et al., 1991; Joiris et al., 1995; Magalhães et $a l ., 2007)$. This is the case for A. carbo, a voracious predator, living at depths of around 1200-1700 m and exhibiting fairly rapid growth rates in the first years of life (Vieira et al., this issue). The median mercury concentrations obtained in this study are in agreement with the levels reported in the literature (Afonso et al., 2007, 2008 and Bebiano et al., 2007). The median total mercury concentrations found in muscle tissues from A. carbo were approximately 5-10 times higher than those reported in other benthopelagic species caught in more northern areas of the Atlantic (Mormede and Davis, 2001b; Cronin et al., 1998). Moreover, our results were within a similar range to those obtained for other deep-water species captured off the Azores (Magalhães et al., 2007) and mainland Portugal (Afonso et al., 2008), and for hydrothermal vent fish species at the MidAtlantic Ridge (Martins et al., 2006).

Total mercury levels observed in black scabbardfish caught off the Azores and Madeira were significantly higher than those caught off the mainland. Potential sources of mercury are the volcanism associated with the expansion of the Mid-Atlantic Ridge and the occurrence of mercury-enriched Mediterranean water, which flows into the North Atlantic at depths below $1000 \mathrm{~m}$ (Johnson and Stevens, 2000). However, the greatest source of mercury seems to be the atmospheric deposition of elemental mercury associated with the global cycle by way of long-range transport (Monteiro et al., 1996).

While little is known about trace metal composition of water masses in the northeast Atlantic, these archipelagos are also characterised by highly dynamic oceanographic, atmospheric and geological processes, namely the North Atlantic gyre, the Azores front, the upwelling off the Iberian Peninsula and the Canary Islands current (Pollard and $\mathrm{Pu}, 1985)$, which can contribute to the dispersal and concentration of pollutants in these areas.

The higher total mercury levels found in specimens from Madeira in comparison with those from the Azores might be related to the size of the specimens analysed. The length of specimens from Madeira was greater (total length $>1150 \mathrm{~mm}$ ) than that of specimens from the Azores, and a higher percentage of females (93\%) was observed in Madeira individuals. Mercury concentrations in tissues increased with fish length (data not shown), so the larger (older) fish showed higher concentrations than the smaller (young) ones. Females showed higher mercury concentrations than males, a result that can be related to differences in growth rates between sexes (Vieira et al., 2009). As mercury accumulation is 
age-dependent, the faster-growing sex (males) exhibit lower concentrations due to higher dilution of pollutant as a result of tissue growth. In addition, the higher total mercury concentrations were found in the highest maturity stages and mostly corresponded to specimens from Madeira, which were also the largest individuals analysed. These differences in maturity stages between regions reflect the reproductive dynamics of this species in the different regions, which is characterised by the inexistence of mature individuals off the mainland (MS: IV and V) and their occurrence only off Madeira (Neves et al., 2009). These observations might constitute a better explanation for the higher mercury concentrations found in Madeiran specimens than in the mainland individuals.

Similarly to mercury, the enrichment of cadmium in the deep sea suggests higher concentrations in benthic than in epipelagic biota (Mormede and Davies, 2001a). The cadmium concentrations in muscle of deep-water fish are generally low in comparison to levels found in the liver (Bustamante et al., 2003). In the present study, median levels of cadmium in the liver of black scabbardfish were 450 times higher than those found in the muscle, in agreement with the results obtained for other deep-water species (Cronin et al., 1998; Hornung et al., 1993; Mormede and Davies, 2001b) and those reported for the same species by Afonso et al. (2007). Cadmium contents were significantly higher in liver and in muscle in mainland individuals than in Azores individuals, and significantly higher in muscle and in gonads than in Madeiran individuals. These findings were expected because this metal is mostly derived from anthropogenic sources (e.g. metallurgical industries).

Lead concentrations in fish muscle are generally lower than in liver, a pattern that is also observed for cadmium (Mormede and Davies, 2001a). In the present study, lead levels found in muscle samples from the three Portuguese regions were of the same magnitude as those reported by Afonso et al. (2007) and Cronin et al. (1998). Our results were also consistent with those observed by Mormede and Davies (2001a) in several deep-water species caught off the Rockall Trough (west Scotland). In agreement with Afonso et al. (2007), we obtained higher lead levels in the Azorean than in the Madeiran specimens, but similar levels between Madeira and the mainland. Furthermore, it was observed that the majority of lead levels in the muscle of specimens collected off the mainland were below the detec- tion limit of this method $(<0.01 \mathrm{mg} / \mathrm{kg} \mathrm{ww})$. The lead levels in gonads and liver were 3 times higher in Azorean specimens than in those found in the other two regions. Though the Azores are distant from a known anthropogenic source of metal pollution, it is also conceivable that the input of lead may originate from remote sources of industrial pollution or from mineral dusts by way of "longrange atmospheric transport". Furthermore, arsenic and other elements such as lead originating in the NW African Sahara have been found in material collected from Azorean "dust-events" (Reis et al., 2002), and may later settle down in the deep sea. In addition, hydrothermal activity associated with nearby shallow- and deep-vent waters can directly contribute to this metal enrichment in deep-water species from this oceanic region (Wallenstein et al., 2009; Cosson et al., 2008).

It is generally accepted that metal concentrations in the organism reflect the exposure in the aquatic environment and the intake through diet (Mormede and Davies, 2001a). A probable reason for the highly significant region effect observed in this study might be the differences in the diet of black scabbardfish from these three geographic areas. Studies on stomach contents of this species in the study region have so far been inconclusive, mainly due to the characteristics of the fishery. In longline fisheries the specimens remain attached to the gear long enough for the stomach contents to be completely digested, resulting in a high rate of emptiness (93\%) (Freitas,1998; Anon, 2000). Nevertheless, older published data have described the existence of lower mesopelagic and upper bathypelagic fish species (e.g. Maul,1961) and more recently Freitas (1998) found crustacean species, cephalopods and fish from the meso- and bathypelagic zones in the stomachs of A.carbo captured in Madeira waters. There is also evidence that black scabbardfish from the mainland feed on the crustacean Aristeus antennatus (I. Figueiredo, pers. com.), so a preferred crustacean diet might explain the higher cadmium concentrations found in mainland specimens than in speciments from the Azores and Madeira, given the fact that crustaceans tend to accumulate cadmium, mainly in the hepatopancreas (ATSDR, 2008). A cephalopod-based diet could also contribute to the intake of toxic metals in black scabbardfish since they also prey on these invertebrates (Nakamura and Parin, 1993, Muus et al., 1998). In a recent study, Lourenço 
et al. (2009) showed significant concentrations of cadmium (0.04-0.33 mg/kg ww), lead (0.02-0.09 $\mathrm{mg} / \mathrm{kg} \mathrm{ww})$ and mercury $(0.05-0.12 \mathrm{mg} / \mathrm{kg} \mathrm{ww})$ in three different species of cephalopods caught off the Portuguese coast. The variability of metal concentrations can be attributed to the availability of different prey (crustaceans, cephalopods and/or fishes) in the Portuguese regions studied. However, without additional data on dietary composition, it is not possible to explain these geographic differences based only on the black scabbardfish diet.

Regarding the metals distribution in the different tissues, it is recognised that the mechanisms by which fish regulate the accumulation of metals may be linked to the metal absorption or elimination processes, which in turn seem related to tissue and organ characteristics (Reinfelder et al., 1998). Black scabbardfish has higher levels of mercury and cadmium in liver than in the other analysed tissues. The high concentrations found in this organ can be explained by the liver's ability to accumulate large amounts of these metals, through the formation of a soluble metal-binding protein, and by its important role in storage, redistribution, detoxification, and transformation of pollutants (Evans et al., 1993; Mormede and Davies, 2001a,b).

The low concentrations of lead in liver and muscle have their origins in several mechanisms that are involved in this metal intake by fishes. Remarkably, there are no known specific metal-binding cytosolic proteins in the liver with high affinity for lead. Thus, rather than being accumulated in the liver, the absorbed lead is quickly distributed to other tissues (Gašpić et al., 2002) such as gonad tissues, as evidenced in this study. To our knowledge, this is the first study that reports on levels of total mercury, cadmium and lead in gonad of black scabbardfish. The inclusion of this organ in ecotoxicological studies allows a better understanding of metal distribution throughout the fish's lifespan.

With regard to public health, muscle is the most important tissue used to estimate metal concentrations since it is mainly used for human consumption. However, the toxic metal content in liver and female gonad should still be an issue of concern because these organs are also consumed in the Madeira archipelago. The median concentrations of mercury found in muscle of black scabbardfish from both the mainland and the Azores were below the limit established by the EU (1.0 $\left.\mathrm{mg} \mathrm{kg}^{-1} \mathrm{ww}\right)$, whereas the median concentration in specimens from Madeira were above this limit. For all the regions, the median total mercury concentrations were above $1.0 \mathrm{mg} \mathrm{kg}^{-1}$ ww in liver and below this limit in gonads. Median lead concentrations were under the limit value $(0.30$ $\mathrm{mg} / \mathrm{kg} \mathrm{ww}$ ) established by the EU (2006, 2008). The limit of $0.05 \mathrm{mg} / \mathrm{kg}$ ww established by the EU (2006, 2008) for cadmium was exceeded in both liver and gonads, but it was not reached in muscle in any of the regions studied.

In view of the high levels of mercury found and some results observed for the other two metals, it is not safe to assume that this species may be consumed regularly and without restrictions. It is advisable to perform a risk analysis in order to evaluate the PTWI (provisional tolerable weekly intake) of black scabbardfish in the overall diet of Portuguese consumers.

Taken together, the presence of high mercury levels in tissues from this benthopelagic species is expected and is related not only to the biochemistry of this metal but also to the ecological and biological characteristics of the species. A.carbo lives at great depths, occupies a high trophic level, is long-lived and is a predator subjected to longer burdens of this contaminant during its lifetime as a consequence of a diet rich in meso- and bathypelagic species.

Regarding cadmium and lead levels, the specimens landed on the mainland were significantly different from those landed in the Azores. Cadmium concentrations were higher in the mainland specimens, whereas lead concentrations were higher in the Azorean specimens. Contrary to the described distribution pattern of mercury, the region is the only factor that explains the observed variability of cadmium and lead levels. This may be related to the absence of biomagnification of these metals. As for cadmium and lead levels, the differences between maturity stages can be related to the energetic and chemical composition oscillations that occur during the reproductive cycle of this species.

In summary, the similarities and dissimilarities observed between regions might be due to differences in trace metal contents in the water, species physiology, and feeding preferences of the fish inhabiting these three Portuguese regions. In view of the fact that the exploration of deep-sea fish stocks has increased greatly, particularly in the North Atlantic, it is important to monitor the levels of metals in abiotic and biotic compartments of these marine ecosystems. Extending our knowledge to the biological cycle of A. carbo, including its feeding 
ecology and sampling in other geographic areas, may not only provide a better understanding of toxic metals bioaccumulation mechanisms but also help to identify black scabbardfish populations within its geographic distribution.

\section{ACKNOWLEDGEMENTS}

This work was supported by Fundação para a Ciência e Tecnologia (project POCTI/CVT/46851/2002) and by the "Programa Nacional de Recolha de Dados da Pesca". We are grateful to Dália Reis, Ângela Canha and João Gil Pereira (DOP/Uaç-Azores) for the sampling and the reproduction and growth analyses in the Azores, and to Sara Reis and Joana Vasconcelos (DSIP-Madeira) for the sampling in Madeira. We also thank Maria Magalhães, Raul Bettencourt and Ruth Higgins for their support and critical reading of the manuscript. We are also grateful to the anonimous reviewers and the english reviewer for proof-reading of the manuscript.

\section{REFERENCES}

Afonso, C., H.M. Lourenço, C. Pereira, M.F. Martins, M.L. Carvalho, M. Castro and M.L. Nunes. - 2008. Total and organic mercury, selenium and -tocopherol in some deep-water fish species. J.Sci. Food Agric., 88: 2543-255.

Afonso, C., H.M. Lourenço, A. Dias, M.L. Nunes and M. Castro. 2007. Contaminant metals in black scabbard fish (Aphanopus carbo) caught off Madeira and the Azores. Food Chem., 101: $120-125$

Anon - 2000. Environment and biology of deep-water species Aphanopus carbo in the NE Atlantic: basis for its management (BASBLACK). Final Report of EU Study Project 97/0084.

ATSDR. - 2008. Draft Toxicological profile for cadmium. Agency for toxic substances and disease registry. Atlanta, Georgia.

Bebiano, M.J., C. Santos, J. Canário, N. Gouveia, D. Sena-Carvalho and C. Vale. -2007 . Hg and metallothionein-like protein in the black scabbardfish Aphanopus carbo. Food and Chem.Toxic., 45: $1443-1452$.

Bustamante, P., P. Bocher, Y. Cherel, P. Miramand and F. Caurant. - 2003. Distribution of trace elements in the tissues of benthic and pelagic fish from the Kerguelen Islands. The Sci. Total Environ., 313: 25-39.

Canli, M. and G. Atli. - 2003. The relationship between heavy metal $(\mathrm{Cd}, \mathrm{Cr}, \mathrm{Cu}, \mathrm{Fe}, \mathrm{Pb}, \mathrm{Zn})$ levels and the size of six Mediterranean fish species. Environ. Pollut., 121: 129-136.

Cosson. R.P, É. Thiébaut, R. Company, M. Castrec-Rouelle, A. Colaço, I. Martins, P.-M. Sarradin and M. J. Bebianno. - 2008. Spatial variation of metal bioaccumulation in the hydrothermal vent mussel Bathymodiolus azoricus. Mar. Env. Res., 65: 405415.

Cronin, M., I.M. Davies, A. Newton, J.M. Pirie, G. Topping and S. Swan. - 1998. Trace metal concentrations in deep-sea fish from the North Atlantic. Mar. Env. Res., 45: 225-238.

Dugo, G., L. La Pera, A. Bruzzese, T.M. Pellicanò and V. Lo Turco. - 2006. Concentration of $\mathrm{Cd}$ (II), $\mathrm{Cu}$ (II), $\mathrm{Pb}$ (II), Se (IV) and Zn (II) in cultured sea bass (Dicentrarchus labrax) tissues from Tyrrhenian Sea and Sicilian Sea by derivative stripping potentiometry. Food Control, 17: 146-152.

Environmental Protection Agency (EPA) - 1999. Toxicological
Review of Cadmium and Compounds and IRIS Summaries for Cadmium and Compounds Federal Register. 64(142): 4036940370.

EU. - 2006. Commission Regulation (EC) No 1881/2006 of 19 December 2006 setting maximum levels for certain contaminants in foodstuffs. JO L364: 5-24.

EU. - 2008. Commission Regulation (EC) No 629/2008 of 2 July 2008 amending Regulation (EC) No 1881/2006 setting maximum levels for certain contaminants in foodstuffs. JO L 173: 6-9.

Evans, D.W., D.K. Dodoo and P.J. Hanson. - 1993. Trace element concentrations in fish livers: implications of variations with fish size in pollution monitoring. Mar. Pollut. Bull., 26: 329-334.

Falcó, G., J.M. Llobet, A. Bocio and J.L. Domingo. - 2006. Daily intake of arsenic, cadmium, mercury and lead by consumption of edible marine species. J. Agric. Food Chem., 54: 6106-6112.

Figueiredo, I., P. Bordalo-Machado, S. Reis, D. Sena-Carvalho, T. Blasdale, A. Newton and L.S. Gordo. - 2003. Observations on the reproductive cycle of the black scabbardfish (Aphanopus carbo Lowe, 1839) in the NE Atlantic. ICES J. Mar. Sci., 60: 774-779.

Freitas, I.C.L. - 1998. Contribuição para o conhecimento da ecologia alimentar do peixe espada preto, Aphanopus carbo Lowe 1839 (Pisces: Trichiuridae) no Arquipelago da Madeira (in Portuguese). 59 pp. Diplom thesis. Department of Biology, University of Madeira.

Gašpić, Z.K., T. Zvonarić, N. Vrgoč, N. Odžak and A. Barić. 2002. Cadmium and lead in selected tissues of two commercially important fish species from Adriatic Sea. Water Res., 36: 5023-5028.

Gordo, L.S., D.S. Carvalho, I. Figueiredo, S. Reis, P.B. Machado, A. Newton, and J. Gordon. - 2000. Escala de maturação sexual do peixe-espada preto: uma abordagem macro e microscópica. The sexual maturity scale of black scabbardfish: a macro- and microscopic approach. Celta Editora, Oeiras.

Gordon, J.D.M., N.R. Merrett and R.L. Haedrich. - 1995. Environmental and biological aspects of slope dwelling fishes. In: A.G. Hopper (ed.), Deep-water fisheries of the North Atlantic Oceanic slope, pp. 1-30. Kluwer Academic Publishers, Dordrecht, The Netherlands.

Hatch, R.W. and L. Ott. - 1968. Determination of sub-microgram quantities of mercury by atomic absorption spectrophotometry. Anal. Chem., 40: 2085-2087.

Hornung, H., M. D. Krom, Y. Cohen and M. Bernhard. - 1993. Trace metal content in deep-water sharks from the eastern Mediterranean Sea. Mar. Biol., 115: 331-338.

Hrudey, S.E., W. Chen and C.G. Roussex. - 1996. Bioavailability in environmental risk assessment. CRC Press, USA.

Joiris, C. R., I.B. Ali, L. Holsbeek, M. Bossicart and G. Tapia. 1995. Total and organic mercury in Barents sea pelagic fish. Bull. Env. Cont. Toxic., 55: 674-681.

Johnson,J. and I. Stevens. - 2000. A fine resolution model of the eastern North Atlantic between the Azores, The Canary Islands and the Gibraltar Strait. Deep Sea Res. I, 47: 875-899.

Jorhem, L. - 2000. Determination of metals in food by atomic absorption spectrometry after dry ashing: NMKL Collaborative study. JAOAC Int., 83(5): 1204-1211.

Lourenço, H.M., P. Anacleto, C. Afonso, V. Ferraria, M.F. Martins, M.L. Carvalho, A.R. Lino and M.L. Nunes. - 2009. Elemental composition of cephalopods from Portuguese continental waters. Food Chem., 113: 1146-1153.

Magalhães, M.C., V. Costa, G.M. Meneses, M.R. Pinho, R.S. Santos and L.R. Monteiro. -2007 . Intra-and inter specific variability in total and methylmercury bioaccumulation by eight marine fish species from the Azores. Mar. Poll. Bull., 54: 1654-1662.

Martins, M.R. and C. Ferreira. - 1995. Line fishing for black scabbardfish Aphanopus carbo Lowe, 1839 and other deep water species in the eastern mid Atlantic to the north of Madeira. In: A.G. Hoppe (ed.), Deep Water Fisheries of the North Atlantic Oceanic Slope, pp. 323-325. Kluwer Academic Publishers, Dordrecht, The Netherlands.

Martins, I., V. Costa, F.M. Porteiro, A. Colaço and R.S. Santos. - 2006. Mercury concentrations in fish species caught at MidAtlantic Ridge hydrothermal vent fields. Mar. Ecol. Prog. Ser., 320: 253-258

Mason R.P, K.R. Rolfhus and W.F. Fitzgerald. - 1995. Methylated and elemental mercury cycling in surface and deep ocean waters 
of the North Atlantic. Wat. Air Soil Pollut., 80: 665-677.

Maul, G.E. - 1961. The Ceratioid Fishes in the Collection of the Museu Municipal do Funchal (Melanocetidae, Himantolophidae, Oneirodidae, Linophrynidae). Boletim do Museu Municipal do Funchal. N ${ }^{\circ} \mathrm{XIV}$, Art. 50: 87-159.

Merrett, N.R. and R.L. Haedrich. - 1997. Deep-sea demersal fish and fisheries. Chapman and Hall, London.

Monteiro, L.R., E.J. Isidro and H. D. Lopes. - 1991. Mercury content in relation to sex, size, age and growth in two scorpionfish (Helicolenus dactylopterus and Pontinus kuhlii) from Azorean waters. Wat. Air Soil Pollut., 56: 359-367.

Monteiro, L.R., V. Costa, R.W. Furness and R.S. Santos. - 1996. Mercury concentrations in prey fish indicate enhanced bioaccumulation in mesopelagic environments. Mar. Ecol. Prog. Ser., 141: $21-25$.

Mormede, S. and I.M. Davies. - 2001a. Heavy metals concentrations in commercial deep-sea fish from the Rockall Trough. Cont. Shelf Res., 21: 899-916.

Mormede, S. and I.M. Davies. - 2001b. Trace elements in deepwater fish species from the Rockall Trough. Fish. Res., 51: 197-206.

Muus, B.J., J.G. Nielsen, P. Dahlstrom and B.O. Nyström. - 1998. Guía de identificatión peces de mar del Atlántico y del Mediterráneo, Ediciones Omega, S.A., Barcelona.

Nakamura, I. and N.V. Parin. - 1993. FAO species catalogue. Vol 15. Snake mackerels and cutlassfishes of the world (families Gempylidae and Trichiuridae). An annotated and illustrated catalogue of the snake mackerels, snoeks, escolars, gemfishes, sackfishes, domine, oilfishes, cutlassfishes, scabbardfishes, hairtails and frostfishes known to date. FAO Fish. Synop., 125 (15): $1-136$

Neves, A., A.R. Vieira, I. Farias, I. Figueiredo, V. Sequeira and L.S. Gordo. - 2009. Reproductive strategies in black scabbardfish (Aphanopus carbo Lowe, 1839) from NE Atlantic. Sci. Mar., 73S2: 19-31.

Parin, N.V. - 1986. Gempylidae, Trichiuridae. In: P.J.P. Whitehead, M.L. Bauchot, J.C. Hureau, J. Nielsen and E. Tortonese (eds.), Fishes of the North-eastern Atlantic and the Mediterranean, pp. 967-973, 976-980, Vol II. UNESCO, Paris.

Paterson C. - 1987. Global pollution measured by lead in mid-ocean sediments. Nature, 326: 244-245.

Pérez-Cid, B., C. Boia, L. Pombo and E. Rebelo. - 2001. Deter- mination of trace metals in fish species of the Ria de Aveiro (Portugal) by electrothermal atomic absorption spectrometry. Food Chem., 75: 93-100.

Pollard, R.T. and S. Pu. - 1985. Structure and circulation of the upper Atlantic Ocean northeast of the Azores. Prog. Oceanogr., 14: 443-462.

Reis, M.A., O.R. Oliveira, L.C. Alves, E.M.C. Rita, F. Rodrigues, P. Fialho, C.A. Pio, M.C. Freitas and J.C. Soares. - 2002. Comparison of continental Portugal and Azores Islands aerosol during a Sahara dust storm. Nuclear Instrum. and Meth. in Phys. Res. Section B: Beam Interactions with Materials and Atoms, 189, Issues 1-4: 272-278.

Reinfelder, J.R., N.S. Fisher, S.N. Luoma, J.W. Nichols and W.-X. Wang. - 1998. Trace elements trophic transfer in aquatic organisms: A critique of the kinetic model approach. The Sci. Total Environ., 219: 117-135.

Riisgård H.U. and S. Hansen. - 1990. Biomagnification of mercury in marine grazing food-chain: algal cells Phaeodactylum tricornutum, mussels Mytilus edulis and flounders Platichthys flesus studied by means of a stepwise-reduction-CVAA method. Mar. Ecol. Prog. Ser., 62: 259-270.

Saltzman B.E, D.W. Yeager and B.G. Meiners. - 1983. Reproducibility and quality control in the analysis of biological samples for lead and mercury. Am. Ind. Hyg. Assoc. J., 44: 263-267.

Storelli, M.M. - 2008. Potential human health risks from metals $(\mathrm{Hg}, \mathrm{Cd}$, and $\mathrm{Pb})$ and polychlorinated biphenyls (PCBs) via seafood consumption: estimation of target hazard quotients (THQs) and toxic equivalents (TEQs). Food Chem. Toxicol., 46: $2782-2788$.

Vieira, A.R., I. Figueiredo, I. Farias, A. Neves, B. Morales-Nin, V. Sequeira, M. R. Martins and L.S. Gordo. - 2009. Age and growth of black scabbardfish (Aphanopus carbo Lowe, 1839 in the southern NE Atlantic. Sci. Mar., 73S2: 33-46.

Wallenstein, F.M., R.P. Couto, A.S. Amaral, M. Wilkinson, A.I. Neto and A.S. Rodrigues. - 2009. Baseline metal concentrations in marine algae from São Miguel (Azores) under different ecological conditions - Urban proximity and shallow water hydrothermal activity. Mar. Pollut. Bull., 58: 424-455.

Scient. ed.: F. Maynou.

Received December 19, 2008. Accepted October 26, 2009.

Published online December 22, 2009. 